\title{
The Open Government Partnership: what are the challenges and

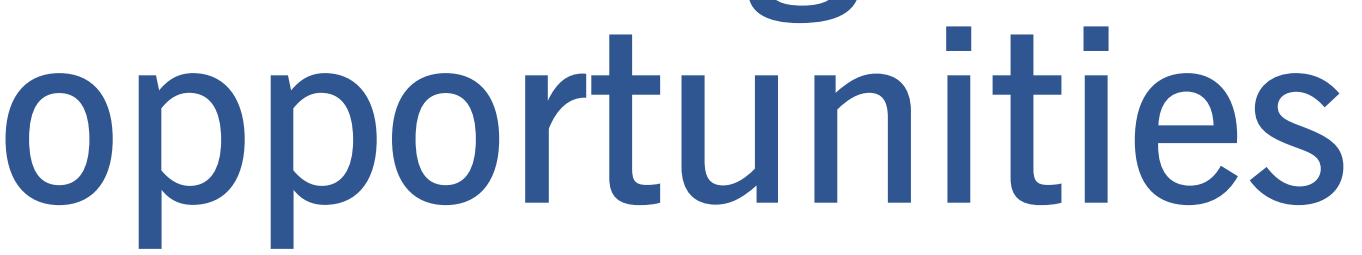 \\ for New Zealand?
}

Introduction

In November 2013 New Zealand signed up to the Open Government Partnership (OGP), which was established in 2011 and comprises 63 nations. The OGP operates as a partnership on two levels: nationally, as a partnership between governments and civil society organisations to effect reforms in various areas; and internationally between nations sharing ideas and good practice and collaborating in areas of transparency, integrity and public safety. Upon announcing New Zealand's participation the state services minister, Jonathan Coleman, declared:

In joining the Open Government Partnership, New Zealand is showing we are committed to promoting open and transparent government, and we look forward to

Michael Macaulay is the Deputy Director of the Institute for Governance and Policy Studies. sharing best practices and expertise with our overseas partners ... The government has established a number of initiatives which deliver more open and accountable government to New Zealanders. The Better Public Services programme shows how the government is tracking on its commitment to delivering better public services. 
Through the Kiwis Count survey, the government publishes up to date information on the quality of service New Zealanders are receiving from public services. (Coleman, 2013)

The conflation of initiatives such as Better Public Services with OGP is very interesting as it arguably broadens the already wide OGP remit, which, as will be shown, is divided into five 'grand challenges'. However, this article will argue that creating such links allows for a potentially more sophisticated discussion than the common academic approach of seeing integrity and transparency as an additional component to public policy.

I will begin by offering a brief history of the OGP and outlining its goals and targets. I will then look at some of the challenges New Zealand faces in meeting its OGP obligations, as well as identifying a selected number of areas in which reform may be realised. Finally, the article will turn to the ambition above and discuss some of the implications of Coleman's statement. The OGP is still very much in its infancy, and this article is not meant to be any kind of evaluation, but rather hopes to point the way to areas of future discussion, and, more importantly, future policy initiatives.

\section{What is the Open Government Partnership?}

The Open Government Partnership was launched on 20 September 2011. In order to gain membership of the OGP, each country must do three things: sign up to the OGP Declaration of Intent; develop an initial two-year action plan; and implement that plan. Currently, 63 countries have signed up to the OGP in four cohorts (see Table 1). Cohort 4 countries, including New Zealand, are in the process of joining the forum and are currently drafting their initial OGP national action plans.

There are a further five 'expectations' attached to OGP membership. All signatories are expected to:

1. endorse the high-level Open Government Declaration;

2. make concrete commitments, as part of a country action plan, that are ambitious and go beyond a country's current practice;

Table 1: OGP membership September 2011-March 2014

\begin{tabular}{ll}
\hline Members of the Open Government Partnership \\
\hline Cohort 1 & Brazil, Indonesia, Mexico, Norway, the Philippines, South Africa, United \\
& Kingdom, United States \\
\hline Cohort 2 & Albania, Armenia, Azerbaijan, Bulgaria, Canada, Chile, Colombia, Croatia, \\
& Czech Republic, Denmark, Dominican Republic, El Salvador, Estonia, \\
& Georgia, Greece, Guatemala, Honduras, Italy, Israel, Jordan, Kenya, \\
& Latvia, Lithuania, Macedonia, Malta, Moldova, Montenegro, Netherlands, \\
& Paraguay, Peru, Romania, Slovak Republic, Spain, South Korea, Sweden, \\
& Tanzania, Turkey, Ukraine, Uruguay \\
\hline Cohort 3 & Argentina, Costa Rica, Finland, Ghana, Hungary, Liberia, Panama \\
\hline Cohort 4 & Australia, Ireland, Malawi, Mongolia, New Zealand, Sierra Leone, Serbia, \\
& Trinidad and Tobago
\end{tabular}

3. develop country action plans through a multi-stakeholder process, with the active engagement of citizens and civil society;

4. commit to a self-assessment and independent reporting on the country's progress in implementing its action plan;

5. contribute to the advancement of open government in other countries through sharing of best practices, expertise, technical assistance, technologies and resources, as appropriate. (taken from OGP, 2014, p.3)

It is intended that, by adhering to these goals, national governments will promote transparency, accountability and citizen engagement, all of which contribute to improvements in good governance. The OGP itself provides a support unit and an independent reporting mechanism to enable country evaluation, which is done through OGP progress reports. In joining the OGP, countries commit to 'foster[ing] a global culture of open government that empowers and delivers for citizens, and advances the ideals of open and participatory 21 st century government'.

The scope of OGP is thus, necessarily, very broad, and the general goals of increased transparency, accountability and engagement have been translated into five 'grand challenges'. These seek to:

1. improve public services;

2. improve public integrity;

3. more effectively manage public resources;

4. create safer communities; and

5. increase corporate accountability.
Within these challenges there is scope for member countries to implement any specific initiatives that each feels are necessary, with the only stipulation being that action plans must include concrete initiatives that can be readily measured.

These are all laudable aims, but it may be tempting for one to exercise a degree of scepticism, if not outright cynicism, about the OGP in light of the myriad examples of government masssurveillance and misuse of data in recent months. Open government seems a long way from the revelations of Edward Snowden and others. However, putting that debate to one side for a moment, there are a number of initiatives that have developed under the auspices of the OGP that give cause for cautious optimism.

Perhaps most encouraging is that many participating states (both OECD and non-OECD countries) appear to be working in authentic collaborations with civil society. While Mexico's first iteration of its action plan contained comparatively little civil society collaboration, it has subsequently consulted with civil society by including representatives on its Technical Tripartite Secretariat, a forum comprising representatives from the Ministry of Public Administration, the Federal Institute for Access to Information and Data Protection and the Civil Society Coordinating Committee, to advance its action plan (OGP Mexico, 2014). Due to the initial low levels of engagement with civil society, Mexico's action plan (201113) went through a second iteration, which developed 36 proposals relating to civil society, of which 20 have been achieved: these include open access to 
official document archives (proposal 34), improvements to electronic procurement (proposal 17), and development of civil society innovation tools (proposal two) (OGP Mexico, 2013). Several other key commitments, including a criminal investigation website, better environmental reporting and a climate change website, are still being developed. Mexico is currently developing its second (2013-15) OGP action plan and is engaging with over 200 participants (drawn from civil society and a number of other areas) working in nine thematic groups. Not only, therefore, has Mexico's to build on existing initiatives), ${ }^{2}$ but it pointed towards a specific issue for which the UK OGP was heavily criticised. In giving priority to ongoing commitments, the engagement process was severely restricted, and engagement with civil society in particular was negligible. The UK 2012-13 progress report noted that:

The UK Government proposed public consultations on its action plan after submitting it to the OGP. It said consultations would be made via its Public Sector Transparency Board and also by convening and

\section{It would be fair to say that relationships between some [civil society organisations] and the government have not always been cordial: indeed, it was only in September 2011 that Prime Minister David Cameron responded to Transparency International UK's research into corruption in the UK ...}

OGP met nearly two-thirds of its proposals, but it has managed to engage positively with an increasingly broad network of civil society respondents.

A similar story can be found in the UK, which has recently published its second OGP action plan. Of the 37 proposals ${ }^{1}$ put forward in the original, 2011-13 action plan, all had been completed or were in progress, including creating an online data monitoring process (proposal 8), establishing a single domain for all online government services (proposal 33), and putting all consultation processes online (proposal 35). However, many of the actions that have been completed were already part of the coalition government's prior commitments to increasing transparency and expanding online services: in other words the original OGP action plan was to a significant degree tailored around existing policies rather than bringing anything new to the table. In essence there is nothing particularly problematic about this approach (indeed, OGP member nations are encouraged consulting with a wider group of stakeholders specifically to consider the country plan. However, it is not clear to what extent structured external consultation took place, if at all. It seems doubtful that any written submissions regarding the 2011 action plan were received as part of a consultative process; none were available online. At the time of research, no record could be located as to which private sector and non-profit organizations or private citizens had made contributions. (Officials who may have known were either no longer in their positions or were unavailable. There was no online material regarding consultations.) In interviews, officials accepted that forewarning notice and prior consultation were not adequate. (Dunion, 2013, p.19)

Elsewhere the consultation process was criticised as being too London-centric, too heavily focused on implementation issues rather than on the action plan itself, and too heavily weighted towards an exclusive and narrowly selected group of stakeholders. In conclusion the progress report suggested that this approach demonstrated 'risks attached to exclusivity and of representing only those selected by government' (ibid., p.21).

What has been heartening to supporters of the OGP is the way in which the UK coalition government has reacted to this criticism. Refreshingly, it has openly acknowledged these criticisms and has recognised that engagement with civil society organisations requires a significant commitment, both temporal and financial. As a result the UK government has made a much more concerted effort at engagement. A Civil Society Network has been established, reporting to the Cabinet Office, which gives civil society organisations direct representation in the action plan process, both broadening and deepening their level of participation. The government's new commitments, such as a commitment to open procurement, are ambitious and levels of engagement are considerably higher.

An immediate example of this more proactive approach is the new commitment to developing a national anti-corruption strategy, which will coordinate cross-government activities into one area. As the United Kingdom's approach to anti-corruption work has previously been identified as a 'patchwork quilt'3 of important but uncoordinated activities, this commitment is extremely welcome. What is perhaps even more welcome, however, is both the number and range of civil society organisations that are involved in developing and implementing the commitment, including the BOND Anti-Corruption Group, made up of Article 19, CAFOD, Christian Aid, Corruption Watch, Global Witness, Integrity Action, ONE, Public Concern at Work, Tearfund, the Corner House and Transparency International UK. ${ }^{4}$ It would be fair to say that relationships between some of these organisations and the government have not always been cordial: indeed, it was only in September 2011 that Prime Minister David Cameron responded to Transparency International UK's research into corruption in the UK 
by stating: 'I am concerned that it the research] reflects a view that corruption is a growing threat but I do not accept that there is a complacency or lack of coherent approach for dealing with the issue' (Cameron, 2011).

These are only two country examples, of course, but progress reports and action plans across the OGP nations frequently tell a similar story: although OGP commitments are a work in progress they are at least progressing - demonstrably so - and they are doing so through serious engagement with civil society organisations and other stakeholders.

\section{The challenges for New Zealand's membership}

In many respects New Zealand starts from a position of strength in terms of the OGP. Some may argue that it seems slightly unusual that it joined comparatively later than other countries, given New Zealand's international reputation for good governance and anti-corruption work. Although debate will continue over issues such as New Zealand's standing as the least corrupt country according to Transparency International's Corruption Perception Index, it is fair to say that New Zealand has long been recognised as a world leader in transparency, integrity and accountability of government. (For an excellent recent analysis of this debate, and the merits of the Corruption Perception Index and other corruption measures, see Gregory, 2014.)

Perhaps a more stinging accusation is that a growing sense of complacency has entered the New Zealand outlook, possibly even as a result of its high international standing. A recent report argued that there may be a sense that New Zealand's overall governance was already considered to be robust enough, and that as a result in some key areas there has been continued passivity and complacency' (TINZ, 2013, p.333). Examples of this include New Zealand's continued delay in ratifying the United Nations Convention on Corruption (UNCAC), which was originally signed over a decade ago, and the lack of investigations (or even allegations) around bribery overseas, despite New Zealand incorporating the OECD Convention on Combating Bribery of Foreign Public Officials in International Business
Transactions into part 6 of the Crimes Act 1961 (see Newman and Macaulay, 2013). Decisions over joining the OGP may be seen in a similar light: New Zealand was invited to join (along with a number of other countries) and representatives attended the initial working-level OGP meeting in Brazil in December 2011, yet it took two further years for New Zealand to make the commitment.

Such an accusation may have greater merit, however, if the government had shown no inclination at all to engage in OGP-type activities. Yet several initiatives were announced around the time of
In terms of ownership, the OGP action plan is currently being developed by the State Services Commission, and while there is no doubt that this is an eminently sensible choice, there needs to be genuine support and an infrastructure of collaboration to ensure that the OGP team attains maximum impact. Of chief importance is the need for a clear sense of New Zealand's OGP commitments to be communicated to all relevant departments to enable a free and frank flow of information. The risk for the OGP action plan is not necessarily that it will lack teeth, but rather that there may be a

\section{... the outcomes-based focus of Better Public Services fits in very neatly with the OGP philosophy of measurable and deliverable results, which means that the New Zealand OGP team are working within a familiar paradigm.}

the OGP being founded, particularly in relation to greater transparency in public data. Chief among these initiatives was the 2011 Declaration on Open and Transparent Government, which heralded the creation of a number of working groups, new principles for data and information management, ${ }^{5}$ and an annual evaluation which charts implementation progress. A number of other key initiatives have also been developed, such as the Data Futures Forum (which reports to the ministers of finance and statistics) and the Community of Practice for Online Engagement (cohosted by the Department of Internal Affairs and Victoria University). In terms of accessibility and transparency of information at least, therefore, any charge of complacency seems premature.

In OGP terms, however, openness of data is only one element of the five grand challenges, albeit one that has figured highly on many countries' agendas. The effectiveness of New Zealand's first action plan arguably rests on three key, interrelated challenges: ownership; engagement; and ambition. range of initiatives and policies currently being carried out are not fully recognised by the OGP team. If this happens, then it cannot be the fault of one team: the OGP is a very broad-ranging initiative and needs to be consciously recognised as such. As ever, cross-departmental communication is critical and it is hoped that, although SSC are spearheading the action plan, they are being assisted by other departments which are ensuring that information is shared freely.

Clearly this is also an engagement risk: to what extent have all relevant departments been given the information and capacity to engage with the lead team and action plan process? This risk applies equally to broader public consultation. As has been seen in the UK, consultation must be an active process and not one that is seen to be done as an afterthought. There has not been a great deal of publicity around the OGP since the initial announcement in 2013, and the extent to which the project is known, let alone understood, by the public is open to question. 
Table 2

\begin{tabular}{|c|c|}
\hline OGP Grand Challenges & NIS Recommendations \\
\hline Improving public services & $\begin{array}{l}\text { - Strengthen role of permanent public sector in regard to } \\
\text { procurement, etc. } \\
\text { - Strengthen governance arrangements, executive and } \\
\text { Parliament } \\
\text { - Publishing a Citizen's Budget }\end{array}$ \\
\hline Improving public integrity & $\begin{array}{l}\text { - Ratification of UNCAC } \\
\text { - National New Zealand anti-corruption strategy } \\
\text { - Support and reinforce roles of Electoral Commission, } \\
\text { judiciary and ombudsman }\end{array}$ \\
\hline $\begin{array}{l}\text { More effectively managing } \\
\text { public resources }\end{array}$ & $\begin{array}{l}\text { - Strengthen role of permanent public sector in regard to } \\
\text { procurement, etc. } \\
\text { - Support and reinforce roles of Electoral Commission, } \\
\text { judiciary and ombudsman } \\
\text { - Greater transparency over public appointments to boards } \\
\text { of Crown entities and other public bodies }\end{array}$ \\
\hline Creating safer communities & $\begin{array}{l}\text { - Strengthen governance arrangements between central } \\
\text { and local government } \\
\text { - Enhance transparency of the judiciary and court system, } \\
\text { including information over judicial appointments }\end{array}$ \\
\hline $\begin{array}{l}\text { Increasing corporate } \\
\text { accountability }\end{array}$ & $\begin{array}{l}\text { - Ensure adequate training on and awareness of corruption } \\
\text { and integrity risks in business } \\
\text { - Investigate and evaluate the costs and benefits to } \\
\text { business of continual vigilance around maintaining and } \\
\text { strengthening integrity systems. }\end{array}$ \\
\hline
\end{tabular}

Yet both of these issues are dependent on what the ambition for the OGP action plan is. Jonathan Coleman's announcement clearly links it to Better Public Services, and, as has been mentioned previously, there are numerous existing initiatives that would lend themselves to OGP activities. In adopting such an outlook, the New Zealand government can at least be assured of creating objectives that can, and are, being met. Yet such an approach equally opens up the action plan to the same criticisms as made in the UK: that by leaning on pre-existing arrangements, the risk is that New Zealand's action plan offers very little that is new or innovative, and even less that could be a product of new engagement with stakeholders.

Better Public Services itself, however, covers at least three of the OGP grand challenges (improving public services, more effectively managing public resources, and creating safer communities) and arguably covers aspects of all five of them. Moreover, the outcomes-based focus of Better Public Services fits in very neatly with the OGP philosophy of measurable and deliverable results, which means that the New Zealand OGP team are working within a familiar paradigm. There are, therefore, some interesting opportunities to anchor OGP within Better Public Services, which could well provide quite a sophisticated way of synthesising New Zealand's domestic policies with global reforms. Obviously there are limits: it would not be helpful to simply replicate Better Public Services reforms directly in the OGP Action Plan, as was the case in the UK. Eyebrows arguably would also be raised if the reference to Better Public Services were limited to one or two BPS result areas. In principle, however, conflating the two programmes is by no means a retrograde step. Yet, as the action plan remains an unknown quantity, the question which goes repeatedly begging is, what will be in it?

\section{What can New Zealand do?}

It is important to recognise that this article is not intended to offer policy advice, and it would be unproductive to provide a wish-list of initiatives that could be asked of the OGP project. Nonetheless, there are a number of areas that have recently been identified as possibly dovetailing with OGP, most clearly by the Transparency International NewZealand's 2013 National Integrity System assessment. Transparency International made seven high-level recommendations in its report, and well over 50 more specific recommendations, chief among which was for New Zealand to fully embrace its OGP commitments. Some of its recommendations are clearly long-term: for example, revising the Official Information Act 1982 (TINZ, 2013, p.341) is clearly beyond the scope of the two-year OGP action plan. Others are far more realistic, however: the development of a comprehensive national anti-corruption strategy, for example, would clearly tie into the grand challenge of improving public integrity, and would also provide a number of specific, measurable commitments (ibid., p.332). Some examples from the TINZ assessment have been mapped against the OGP grand challenges in Table 2.

Obviously such ideas are outside the scope of Better Public Services, and therefore may not fit into the current OGP agenda, but it is worth considering that even in a two-year action plan, commitments can be made to ensuring a firm infrastructure for continuing reform. Developing such an infrastructure would deal directly with the issue of engagement, which can build public engagement through online discussion forums and other forms of consultation. There are many important links and networks that have already been developed through the consultation process over Better Public Services, and these should be reopened. Others will need to be developed, but again there are time and resource constraints. What is essential for New Zealand's OGP development is to maintain a sense of realism about what can be done in the first year of membership. As the case studies above have demonstrated, even after a relatively slow start engagement can be created in a meaningful and sustained way, and perhaps the New Zealand OGP team might consider the creation of such consultative groups (a corporate governance group; a civil society group) an end in itself, ready for the action plan. 
Creating a balance of short-, mediumand long-term commitments appears to be the key to moving forward. Too few commitments, or using a very narrow focus for commitments, could lead to the charge of lacking ambition. Yet the initial action plan can lay the groundwork for the future by committing to developing the networks and engagement processes to take it forward, beyond Better Public Services and towards a broader remit still.

\section{Conclusion}

The Open Government Partnership presents an excellent opportunity for New Zealand to tackle concerns about complacency over issues of good gover- nance. Furthermore, it presents an avenue for New Zealand to take a leading role on the world stage in an area in which it already commands a great deal of respect. The challenge now is to balance ambition with realism. The OGP action plan should contain some headline reforms in order to demonstrate New Zealand's commitment to the programme. Yet it does not need to promise too much too soon. The initial action plan can be used to instigate quick wins (such as ensuring the ratification of UNCAC) and provide the infrastructure for future reform (through developing civil society groups, business consultation groups, etc.). There are areas that need a long-term perspective, and these cannot and should not be tackled in the first OGP action plan. They can and should, however, be addressed as a long-term OGP view, one which fits in neatly with the outcomes and spirit of Better Public Services, and one which will hopefully lead to lasting and positive reform.

\footnotetext{
The UK OGP initially put forward 41 proposals but four were withdrawn. It should also be noted that despite its UK focus, there are specific commitments from the Scottish government contained within the UK OGP action plans.

2 See http://www.opengovpartnership.org/how-it-works/actionplans\#sthash.PIUJmEFu.dpuf (accessed 6 April 2014).

National Integrity System studies.

4 Details of the commitment can be found at http:// www.opengovpartnership.org/country/united-kingdom/ commitment/anti-corruption (accessed 6 March 2014).

5 See http://ict.govt.nz/programmes/open-and-transparentgovernment/new-zealand-data-and-information-managementprinci/ (accessed 20 March 2014).
}

\section{Appendix 1: The Open Government Partnership Declaration}

September 2011

As members of the Open Government Partnership, committed to the principles enshrined in the Universal Declaration of Human Rights, the UN Convention against Corruption, and other applicable international instruments related to human rights and good governance:

We acknowledge that people all around the world are demanding more openness in government. They are calling for greater civic participation in public affairs, and seeking ways to make their governments more transparent, responsive, accountable, and effective.

We recognize that countries are at different stages in their efforts to promote openness in government, and that each of us pursues an approach consistent with our national priorities and circumstances and the aspirations of our citizens.

We accept responsibility for seizing this moment to strengthen our commitments to promote transparency, fight corruption, empower citizens, and harness the power of new technologies to make government more effective and accountable.

We uphold the value of openness in our engagement with citizens to improve services, manage public resources, promote innovation, and create safer communities. We embrace principles of transparency and open government with a view toward achieving greater prosperity, well-being, and human dignity in our own countries and in an increasingly interconnected world.

Together, we declare our commitment to: Increase the availability of information about governmental activities. Governments collect and hold information on behalf of people, and citizens have a right to seek information about governmental activities. We commit to promoting increased access to information and disclosure about governmental activities at every level of government. We commit to increasing our efforts to systematically collect and publish data on government spending and performance for essential public services and activities. We commit to pro-actively provide high-value information, including raw data, in a timely manner, in formats that the public can easily locate, understand and use, and in formats that facilitate reuse. We commit to providing access to effective remedies when information or the corresponding records are improperly withheld, including through effective oversight of the recourse process. We recognize the importance of open standards to promote civil society access to public data, as well as to facilitate the interoperability of government information systems. We commit to seeking feedback from the public to identify the information of greatest value to them, and pledge to take such feedback into account to the maximum extent possible.

\section{Support civic participation.}

We value public participation of all people, equally and without discrimination, in decision making and policy formulation.

Public engagement, including the full participation of women, increases the effectiveness of governments, which benefit from people's knowledge, ideas and ability to provide oversight. We commit to making policy formulation and decision making more transparent, creating and using channels to solicit public feedback, and deepening public participation in developing, monitoring and evaluating government activities. We commit to protecting the ability of not-for-profit and civil society organizations to operate in ways consistent with our 


\section{Appendix 1: The Open Government Partnership Declaration (continued)}

commitment to freedom of expression, association, and opinion. We commit to creating mechanisms to enable greater collaboration between governments and civil society organizations and businesses.

\section{Implement the highest standards of professional integrity} throughout our administrations.

Accountable government requires high ethical standards and codes of conduct for public officials. We commit to having robust anti-corruption policies, mechanisms and practices, ensuring transparency in the management of public finances and government purchasing, and strengthening the rule of law. We commit to maintaining or establishing a legal framework to make public information on the income and assets of national, high ranking public officials. We commit to enacting and implementing rules that protect whistleblowers. We commit to making information regarding the activities and effectiveness of our anticorruption prevention and enforcement bodies, as well as the procedures for recourse to such bodies, available to the public, respecting the confidentiality of specific law enforcement information. We commit to increasing deterrents against bribery and other forms of corruption in the public and private sectors, as well as to sharing information and expertise.

\section{Increase access to new technologies for openness and accountability.}

New technologies offer opportunities for information sharing, public participation, and collaboration. We intend to harness these technologies to make more information public in ways that enable people to both understand what their governments do and to influence decisions. We commit to developing accessible and secure online spaces as platforms for delivering services, engaging the public, and sharing information and ideas. We recognize that equitable and affordable access to technology is a challenge, and commit to seeking increased online and mobile connectivity, while also identifying and promoting the use of alternative mechanisms for civic engagement. We commit to engaging civil society and the business community to identify effective practices and innovative approaches for leveraging new technologies to empower people and promote transparency in government. We also recognize that increasing access to technology entails supporting the ability of governments and citizens to use it. We commit to supporting and developing the use of technological innovations by government employees and citizens alike. We also understand that technology is a complement, not a substitute, for clear, useable, and useful information.

We acknowledge that open government is a process that requires ongoing and sustained commitment. We commit to reporting publicly on actions undertaken to realize these principles, to consulting with the public on their implementation, and to updating our commitments in light of new challenges and opportunities.

We pledge to lead by example and contribute to advancing open government in other countries by sharing best practices and expertise and by undertaking the commitments expressed in this declaration on a non-binding, voluntary basis. Our goal is to foster innovation and spur progress, and not to define standards to be used as a precondition for cooperation or assistance or to rank countries. We stress the importance to the promotion of openness of a comprehensive approach and the availability of technical assistance to support capacity- and institution-building.

We commit to espouse these principles in our international engagement, and work to foster a global culture of open government that empowers and delivers for citizens, and advances the ideals of open and participatory 21 st century government.

\section{References}

Cameron, D. (2011) Letter from the prime minister on corruption in the UK report, http://www.transparency.org.uk/our-work/publications/131letter-from-the-prime-minister-on-corruption-in-the-uk-report, accessed 17 March 2014

Coleman, J. (2013) 'NZ to join Open Government Partnership', press release, 1 November, http://www.beehive.govt.nz/release/nz-join-opengovernment-partnership, accessed 5 March 2014

Dunion, K. (2013) United Kingdom Progress Report 2011-2013, OPG Independent Reporting Mechanism, http://www.opengovpartnership. org/country/united-kingdom/progress-report/report, accessed 17 March 2014

Gregory, R.W. (2014) 'Assessing "good governance": "scientific" measurement and political discourse', Policy Quarterly, 10 (1), pp.15-25

Newman, C. and M. Macaulay (2013) 'Placebo or Panacea: Anglo-New Zealand experiences of legislative approaches to combatting bribery', Journal of Criminal Law, 77 (6), pp.482-96

OGP (2014) Open Government Partnership: articles of governance, http://www.opengovpartnership.org/node/1329, accessed 27 March 2014

OGO Mexico (2013) Progress Report 2011-13, available at http://www. opengovpartnership.org/country/mexico, accessed 16 March 2014

OGO Mexico (2014) Open Government Partnership: action plan, http:// www.opengovpartnership.org/country/mexico/action-plan, accessed 2 April 2014

TINZ (2013) Integrity Plus 2013: New Zealand National Integrity System Assessment, Wellington: Transparency International New Zealand 


\section{Al Morrison}

\section{Picking up the Pace in Public Services}

Introduction

\section{Following the reforms of the public management system} in the 1980s, legislative change and programmes of work to develop and shape the system have occurred at various times. The work programmes have tended to come and go, with mixed success, each designed around maintaining the strengths that accountability for outputs has brought to public sector agencies while increasing the focus on achieving outcomes.

The Better Public Services programme currently under way is the latest manifestation. In essence, it is about the system reform required to get the public services to think and operate across the whole government system and beyond to effectively address complex issues that have been holding New Zealand back from continuing prosperity, and to create opportunities through collaborative endeavour. As with past efforts, it is about retaining the strengths of individual agency accountability within a system which encompasses collective responsibility. If the stop-go history of reform since the 1980s is to be avoided, then the task for the public sector is to build continuity and momentum around the current reform and embed it into the whole-of-government system. This means a state services system that is widely recognised as supporting the government of the day, meeting agency accountabilities, and being an excellent steward of public resources for the benefit of present and future generations of New Zealanders.

This article traces aspects of the state sector management system from the 1980 s to the present day with a view to identifying the threads that weave through the various periods of activity. The objective is to bring to the surface the continuity of thought and action that is the basis for a smooth and continuous pathway to enduring reform.

\section{The spirit of reform}

In 2013 Parliament passed some significant changes to the State Sector, Public Finance and Crown Entities acts. The two major parties supported the state sector changes, and minor party objections did not run counter to the fundamental direction of change. All parties supported the public finance and Crown entities changes. The direction of change was to strengthen the accountability of state sector agencies to work better together on problems and opportunities that required collaborative effort, and to make it easier for them to do so. The cross-party support may have defined the common position without meeting the full appetite for change, but it was a good indication of the agreed broad direction of change.

The legislative changes were designed to support the government's Better Public Services programme. That programme continues a reform pathway that has been developing through successive governments since the reforms of the 1980s. The reform pathway has not been 